\title{
Structural and catalytic properties of Ni-Co spinel and its composites
}

\author{
IRYNA IVANENKO ${ }^{1, *} \mathbb{D}$, ANASTASIIA VORONOVA ${ }^{1}$, IHOR ASTRELIN ${ }^{1}$ \\ and YURII ROMANENKO ${ }^{2}$ \\ ${ }^{1}$ Department of Inorganic Substances Technology, Water Treatment and General Chemical Engineering, National \\ Technical University of Ukraine, Igor Sikorsky Kyiv Polytechnic Institute, Kyiv 03056, Ukraine \\ ${ }^{2}$ Department of High-Temperature Materials and Powder Metallurgy, National Technical University of Ukraine, Igor \\ Sikorsky Kyiv Polytechnic Institute, Kyiv 03056, Ukraine \\ *Author for correspondence (irinaivanenko@hotmail.com)
}

MS received 18 September 2018; accepted 20 January 2019; published online 27 May 2019

\begin{abstract}
Pure nickel-cobalt (Ni-Co) spinel and its two composites with active carbon and multi-walled carbon nanotubes (MWCNTs) were synthesized. X-ray diffraction confirmed the nickel cobaltites of cubic syngony and lattice constants for nanosized crystallites. Fourier transform infrared spectra confirmed an inverse spinel consisting of a tetrahedral site $\mathrm{Co}^{2+}$ and octahedral sites $\mathrm{Ni}^{2+}$ and $\mathrm{Co}^{2+}$. Scanning electron microscopy images demonstrated a surface texture typical for spinels and agglomerates of composite particles with active carbon and MWCNTs. All the synthesized samples have a surface area and porosity that are sufficient for the flow of heterogeneous catalytic processes. The micropore volume of the composite with MWCNTs constituted only $4 \%$ of the total porosity, while this percentage represented $25 \%$ for the composite on the basis of active carbon. The high catalytic activity of $\mathrm{Ni}-\mathrm{Co}$ spinel is proved in the model reaction of borohydride hydrolysis. To create composite spinel catalysts, active carbon showed itself to be a more efficient carrier for the catalytically active mass of spinel, as compared to MWCNTs.
\end{abstract}

Keywords. Composite; spinel; active carbon; carbon nanotubes.

\section{Introduction}

A search for clean energy to replace the energy of fossil fuels is an urgent need of the hour. Hydrogen is considered a suitable candidate for producing clean and sustainable fuels due to its availability, high energy density and absence of pollution [1-3].

A relatively safe and inexpensive way to generate enough hydrogen is by hydrolysis of borohydrides (for example, sodium borohydride contains $\sim 10.6 \mathrm{wt} \%$ of hydrogen). However, the hydrolysis of sodium borohydride does not occur at room temperature; therefore, it is necessary to select an effective and stable catalyst.

In 2006, Chandra and Xu [4] demonstrated for the first time that noble metals, such as $\mathrm{Pt}, \mathrm{Rh}$ and Pd exhibit high catalytic activity towards borohydride hydrolysis at room temperature.

After this discovery, many combinations of catalysts and catalytic masses using noble metals were proposed, for example: $\mathrm{Au}, \mathrm{Pt}$ and Pd bulk electrodes [5,6], palladium layers on $\operatorname{Pt}(111)$ [7], $\operatorname{Pt}(111)$ and $\operatorname{Pt}(111)$ modified by a pseudomorphic Pd monolayer [8], Pt/C, AuPt/C and Au/C [9,10], $\mathrm{Pt}, \mathrm{Ag}$ and alloyed Pt-Ag [11], Pt nanoparticles immobilized in mesoporous silica-coated magnetic nanocapsules [12], Ru-Co-PEDOT nanocomposites [13], PdNix-B/carbon nanotube-catalysed anode [14] and platinum/polypyrrolecarbon electrocatalysts [15].

However, the use of expensive catalysts based on noble metals makes such a method to obtain clean energy unprofitable and hinders the development in this direction. Therefore, many scientists have proposed alternative catalysts that do not contain noble metals, such as: $\mathrm{Co}_{3} \mathrm{O}_{4}$ hollow fibre [16], bimetallic Co-Ni-based complex catalyst [17-19], Nipolymer nanogel hybrid particles [20], chitosan-mediated $\mathrm{Co}-\mathrm{Ce}-\mathrm{B}$ nanoparticles [21], $\mathrm{Co}-\mathrm{B}$ [22], Ni-Co-B hollow nanospheres [23], salicylaldimine-Ni complex supported on $\mathrm{Al}_{2} \mathrm{O}_{3}$ [24], $\mathrm{Cu}-\mathrm{Fe}-\mathrm{B}$ nanopowders [25], hydroxyapatitesupported cobalt $(0)$ nanoclusters [26] and many others. Various composite catalytic masses and composites have also been proposed: $\mathrm{NaBH}_{4}-\mathrm{NH}_{3} \mathrm{BH}_{3}$ composite promoted by $\mathrm{AlCl}_{3}$ [27], $\mathrm{MgH}_{2}-\mathrm{LiNH}_{2}$ [28], $\mathrm{Co}-\mathrm{Co}_{2} \mathrm{~B}$ and $\mathrm{Ni}-\mathrm{Ni}_{3} \mathrm{~B}$ [29], $\mathrm{CoCl}_{2}$ on PAN [30], $\mathrm{Mg}$-oxide composites [31], $\mathrm{CoB}$ on $\mathrm{SiO}_{2}$ [32], $\mathrm{Co}-\mathrm{B} /$ glassy carbon and $\mathrm{Co}-\mathrm{B} /$ graphite [33], $\mathrm{CuFe}_{2} \mathrm{O}_{4} / \mathrm{RGO}$ [34], Co@ C [35], Co-W-P/carbon cloth [36], cellulose-based hydrogel-nanometal composites [37], magnetically recyclable [38] and many others.

However, achieving the high catalytic activity of catalysts without precious metals still failed. Therefore, the development of new types of inexpensive catalysts with high catalytic 
activity in relation to the hydrolysis of sodium borohydride remains a relevant scientific and practical task.

From this point of view, simple and complex transition metal oxides with nanostructural characteristics deserve a detailed and careful study because of their advantages of the high surface-to-volume ratio and short path length for diffusion in comparison with their bulky counterparts $[39,40]$.

Spinels are complex transition metal oxides made up of a regular combination of oxygen with the general formula $\mathrm{AB}_{2} \mathrm{O}_{4}$. The most common type of cubic spinels contains tetrahedral (A site) and octahedral (B site) crystalline sites; the cations are distributed among tetrahedral and octahedral sites for their comfortable fit. Their properties could be easily tuned by a suitable distribution of cations in the spinel structure and/or spinels over the developed surface of porous carriers [39-43].

It is known that the structure and properties of spinels, and hence, the processes with their use, strongly depend on the method by which they are obtained. Nanoscale $\mathrm{NiCo}_{2} \mathrm{O}_{4}$ has been successfully synthesized by various methods including sol-gel [40], hydrothermal [44], solid-state reaction [45], coprecipitation [46], mechanochemical [47], rheological phase reaction method [48], surfactant-assisted refluxing method [42], combustion [49], pulsed wire discharge, arc plasmaassisted gas phase synthesis method, microemulsion, electrospinning, thermolysis of mixed metal-oleate complexes and sonochemical [50-55].

In the present study, we studied the catalytic activity of cobaltite nickel spinel type not only in the pure form, but also as a deposit on the surface of two different porous carriers with a developed surface: activated carbon and multi-walled carbon nanotubes (MWCNTs).

For this purpose, pure spinel and its two composites with active carbon and MWCNTs were synthesized by applying a simple and cost-effective co-precipitation method. Their structure and adsorption characteristics were investigated; comparative study of their catalytic activities was carried out.

\section{Experimental}

A simple and cost-effective co-precipitation synthesis method was used for the preparation of samples. During the first stage of the synthesis, the saturated solutions of nickel and cobalt hexahydrates $\left(\mathrm{Ni}\left(\mathrm{NO}_{3}\right)_{2} \cdot 6 \mathrm{H}_{2} \mathrm{O}\right.$ and $\left.\mathrm{Co}\left(\mathrm{NO}_{3}\right)_{2} \cdot 6 \mathrm{H}_{2} \mathrm{O}\right)$ with concentrations of 0.8 and $0.4 \mathrm{~mol} \mathrm{l}^{-1}$, respectively, were prepared to obtain a spinel of stoichiometric composition. Equal volumes of the obtained solutions were mixed and the $\mathrm{pH} 12.4$ was adjusted using sodium hydroxide. The resulting mixture was stirred for $40 \mathrm{~min}$ and left for ageing for 7 days. The obtained precipitate was filtered on a Buchner funnel, dried in a drying cabinet for $1 \mathrm{~h}$ at $110^{\circ} \mathrm{C}$, and then calcined in a muffle furnace at $350^{\circ} \mathrm{C}$ for $3 \mathrm{~h}$. Thus, a sample of $\mathrm{NiCo}_{2} \mathrm{O}_{4}$ was obtained.

For the synthesis of spinel composites, the nitrate coprecipitation method was used as described above. Active carbon Norit SAE SUPER was added, while mixing the initial
Table 1. Designation of samples.

\begin{tabular}{|c|c|c|}
\hline Samples & Composition & $\begin{array}{c}\text { Theoretical bulk } \\
\text { content, } \%\end{array}$ \\
\hline $\mathrm{NiCo}_{2} \mathrm{O}_{4}$ & $\mathrm{NiCo}_{2} \mathrm{O}_{4}$ & 100 \\
\hline $\mathrm{AC}-\mathrm{NiCo}_{2} \mathrm{O}_{4}$ & $\begin{array}{l}\text { Active carbon, } \\
\mathrm{NiCo}_{2} \mathrm{O}_{4}\end{array}$ & $\begin{array}{l}85 \\
15\end{array}$ \\
\hline MWCNT-NiCo $2 \mathrm{O}_{4}$ & $\begin{array}{l}\text { Multi-walled carbon } \\
\text { nanotubes, } \\
\mathrm{NiCo}_{2} \mathrm{O}_{4}\end{array}$ & $\begin{array}{l}85 \\
15\end{array}$ \\
\hline
\end{tabular}

solutions from the theoretical calculation of $15 \%$ mass content. The obtained composite was named as $\mathrm{AC}-\mathrm{NiCo}_{2} \mathrm{O}_{4}$.

The initial MWCNTs were obtained by a CVD method from acetylene at a temperature of $600^{\circ} \mathrm{C}$ and cleaned by concentrated nitric acid while boiling for $1 \mathrm{~h}$ and subsequent washing with distilled water [56]. MWCNTs were added while mixing the initial solutions of hexahydrates from the theoretical calculation of $15 \%$ mass content. This composite was named as MWCNT-NiCo $\mathrm{O}_{4}$.

Thus, three samples were obtained, the designation of which is presented in table 1 .

$\mathrm{X}$-ray diffraction (XRD) patterns were recorded using an $\mathrm{X}$-ray powder diffractometer TTR3 Rigaku, Japan with $\mathrm{CuK} \alpha$ radiation ( $\lambda=15,406 \AA$ ), $30 \mathrm{~mA}$ and $40 \mathrm{~V}$. Thermogravimetric (TG) analysis was performed on a NETZSCH TG 209F1. A total of $\sim 5 \mathrm{mg}$ of material was heated from 25 to $1000^{\circ} \mathrm{C}$ at the ramping rate of $10^{\circ} \mathrm{C} \mathrm{min}^{-1}$ under $\mathrm{O}_{2}$ and $\mathrm{N}_{2}$ mix gas (1:4). Infrared spectra with Fourier transform were recorded using a Nicolet Nexus 470 spectrometer. Parameters of the instrument: operating range of $8000-400 \mathrm{~cm}^{-1}$ and resolution of $0.5 \mathrm{~cm}^{-1}$. The samples were compressed into tablets with $\mathrm{KBr}$ (1-2\% by weight). Scanning electron microscopy (SEM) was performed on a SELMI at an accelerating voltage of $10 \mathrm{keV}$.

The low-temperature adsorption-desorption isotherms of nitrogen onto synthesized samples were obtained on a Quantachrome Nova 1000e apparatus. To study the reliable pore size distributions, both adsorption and desorption curves were used by fitting the data for several well-known adsorption models: Brunauer-Emmett-Teller, Barrett-Joyner-Halenda, Dollimore-Heal, Horvath-Kawazoe and the density functional theory.

The catalytic activity of the synthesized samples was investigated at atmospheric pressure and at a temperature of $60^{\circ} \mathrm{C}$ by the volumetric method in a model of oxidation-reduction liquid-phase heterogeneous catalytic reaction of sodium borohydride decomposition (as a carrier of hydrogen, $10.6 \%$ by weight): $\mathrm{NaBH}_{4}+2 \mathrm{H}_{2} \mathrm{O}=4 \mathrm{H}_{2}+\mathrm{NaBO}_{2}$.

\section{Results and discussion}

On the XRD pattern of pure $\mathrm{NiCo}_{2} \mathrm{O}_{4}$ (figure 1a), all significant peaks of nickel cobaltites in accordance with the 


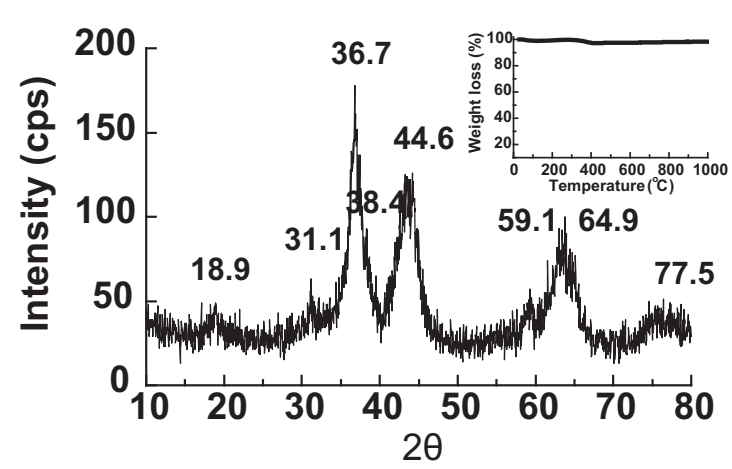

(a)

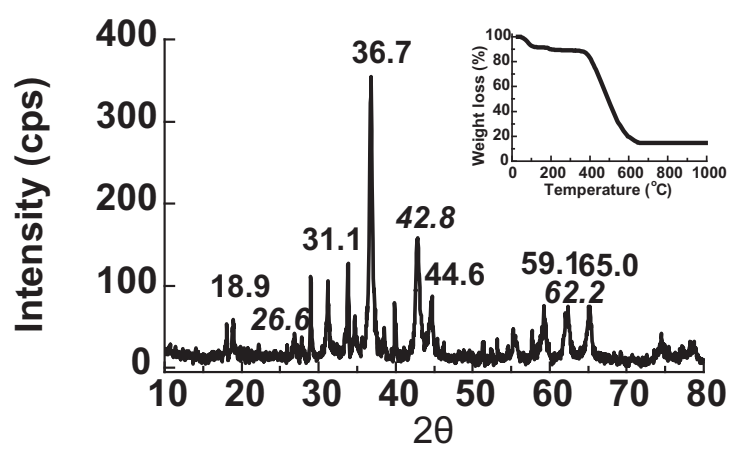

(b)

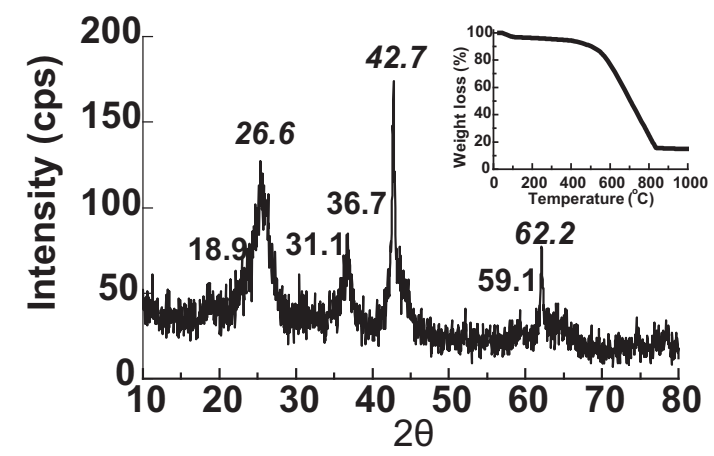

(c)

Figure 1. XRD patterns and TG curves of (a) $\mathrm{NiCo}_{2} \mathrm{O}_{4} ;$ (b) $\mathrm{AC}-\mathrm{NiCo}_{2} \mathrm{O}_{4}$ and (c) MWCNT- $\mathrm{NiCo}_{2} \mathrm{O}_{4}$.

Table 2. Lattice constants of $\mathrm{NiCO}_{2} \mathrm{O}_{4}$.

\begin{tabular}{|c|c|c|c|c|c|c|}
\hline Samples & $\mathrm{a}(\AA)$ & b $(\AA)$ & c $(\AA)$ & $\alpha\left(^{\circ}\right)$ & $\beta\left(^{\circ}\right)$ & $\gamma\left({ }^{\circ}\right)$ \\
\hline $\mathrm{NiCo}_{2} \mathrm{O}_{4}$ & 8103 & 8103 & 8103 & 90,000 & 90,000 & 90,000 \\
\hline $\mathrm{AC}-\mathrm{NiCo}_{2} \mathrm{O}_{4}$ & 8104 & 8104 & 8104 & 90,000 & 90,000 & 90,000 \\
\hline MWCNT-NiCo $2 \mathrm{O}_{4}$ & 8093 & 8093 & 8093 & 90,000 & 90,000 & 90,000 \\
\hline
\end{tabular}

standard card were found and no peaks that would belong to pure oxides or any other substances were observed. The peaks on the XRD pattern of pure $\mathrm{NiCO}_{2} \mathrm{O}_{4}$ at $2 \theta$ values of $18.9 ; 31.1 ; 36.7 ; 38.4 ; 44.6 ; 59.0$ and $65.0^{\circ}$ (figure $1 \mathrm{a}$ ) are attributed to nickel cobalt oxide (111), (220), (311), (222), (400), (511) and (440), respectively (ICDD 00-020-0781).

On XRD profiles of composite samples (figure $1 \mathrm{~b}$ and c), in addition to the peaks of nickel cobaltite, there are also peaks related to carbon: $2 \theta$ values at $26.6 ; 42.7$ and $62.2^{\circ}$ are attributed to (005), (101) and (108), according to ICDD 0000-026-1077.

As seen in figure 1, TG curves indicate a content of $\sim 2 \%$ of the moisture and absorbed water in all the samples. They also evidence the high thermal stability of pure spinel, and also confirm the content of $\sim 15 \%$ of $\mathrm{NiCo}_{2} \mathrm{O}_{4}$ in both the composites.

Lattice constants of pure $\mathrm{NiCo}_{2} \mathrm{O}_{4}$ confirming nanosized crystallites, and cubic syngony of synthesized spinels are presented in table 2 . The composite with activated carbon has the smallest crystallites, but the largest crystallites belong to the composite based on MWCNTs.

Nickel dicobalt(III) oxide is an inverse spinel in which the unit cell consists eight atoms in the $\mathrm{NiCo}_{2} \mathrm{O}_{4}$ molecule. Half of the cobalt ions occupy the tetrahedron plot and the other half of the ions occupy the octahedral plot. It can be represented by the formula $\left(\mathrm{Co}^{2+}\right)_{\mathrm{A}}\left(\mathrm{Ni}^{2+} \mathrm{Co}^{2+}\right)_{\mathrm{B}} \mathrm{O}_{4}$, where $\mathrm{A}$ and $\mathrm{B}$ represent the tetrahedral and octahedral sites, respectively. The Ni-O and $\mathrm{Co}-\mathrm{O}$ complexes in the octahedral position are different from the $\mathrm{Co}-\mathrm{O}$ complex in the tetrahedral position due to the lower mass and lower charge of $\mathrm{Ni}^{2+}$ ions than the $\mathrm{Co}^{2+}$ ion. Also, the cation-oxygen bond strength (cationoxygen force constant) varies spatially [57].

The tetrahedral sites of pure $\mathrm{NiCo}_{2} \mathrm{O}_{4}$ contain $\mathrm{Co}^{2+}$ ions coordinated by four $\mathrm{O}^{2-}$ ions. For this sample, the absorption band (figure $2 \mathrm{a}$ ) corresponding to the tetrahedral complexes (the first band), $v_{1}$, which consists of four sub-bands: $v_{1}(1)$ 


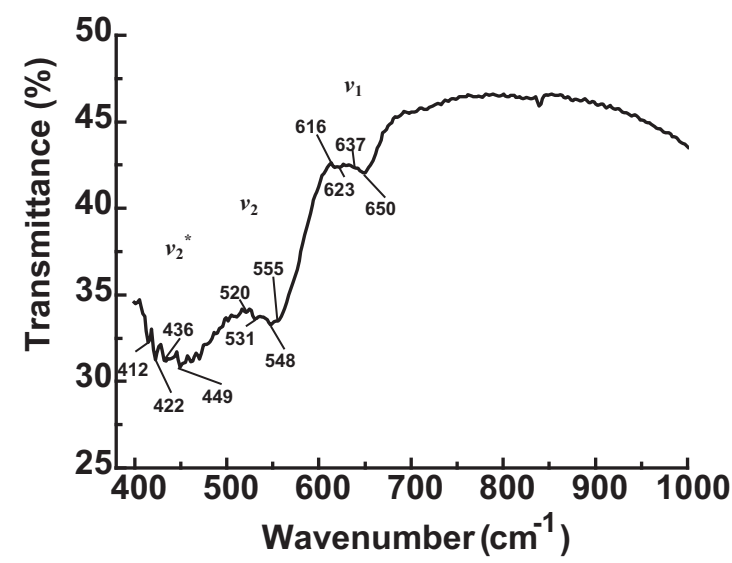

(a)

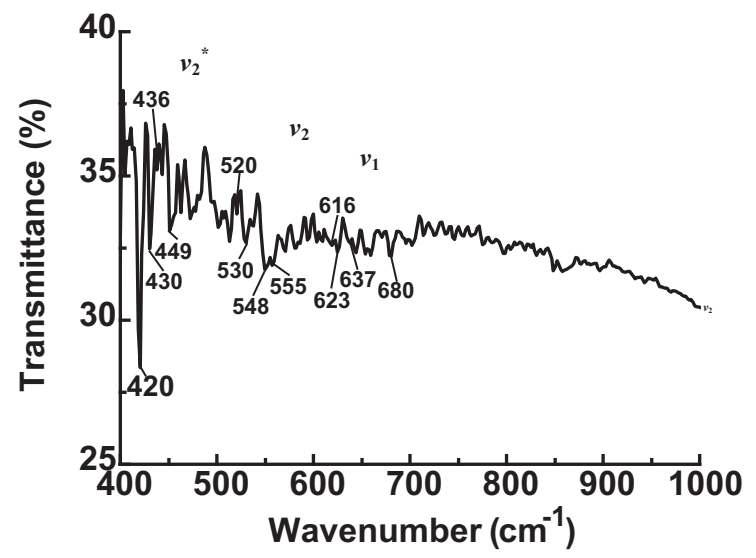

(c)

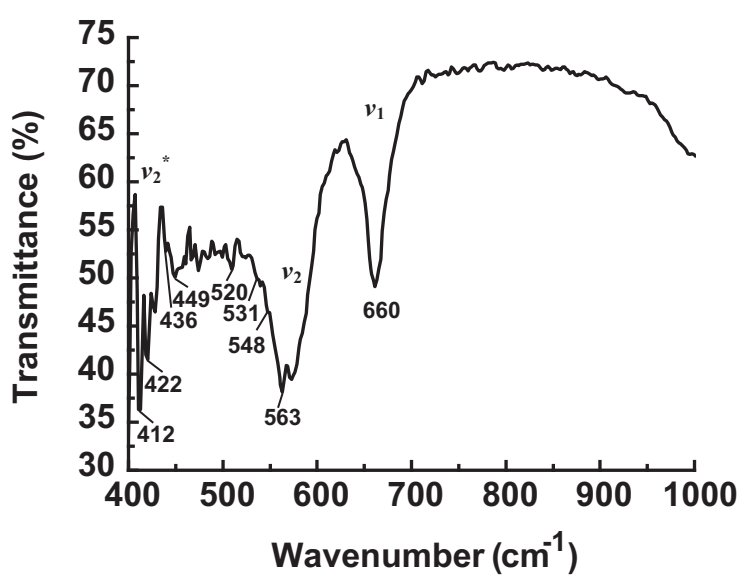

(b)

Figure 2. FTIR spectra of (a) $\mathrm{NiCo}_{2} \mathrm{O}_{4}$; (b) $\mathrm{AC}-\mathrm{NiCo}_{2} \mathrm{O}_{4}$ and (c) $\mathrm{MWCNT}-\mathrm{NiCo}_{2} \mathrm{O}_{4}$.

centred at $\sim 650, v_{1}(2)$ at $\sim 637, v_{1}(3)$ at $\sim 623$ and $v_{1}(4)$ at $\sim 616 \mathrm{~cm}^{-1}$, was detected.

If only the $\mathrm{Co}^{2+}$ ions had been present at the octahedral site, the octahedral band would have been single. However, in the octahedral region, there are two shoulders: $v_{2}$ and $v_{2}^{*}$ as shown in figure $2 \mathrm{a}$. The splitting of this octahedral IR absorption band is due to the large difference in the reduced mass of the octahedral $\left(\mathrm{Ni}^{2+}\right.$ and $\left.\mathrm{Co}^{2+}\right)$ complexes. The octahedral absorption band $\left(v_{2}\right)$ of the pure $\mathrm{NiCo}_{2} \mathrm{O}_{4}$, like the tetrahedral IR-absorption band, is also split into four sub-bands of $\mathrm{Co}^{+2}$ : $v_{2}(1)$ at $\sim 555 \mathrm{~cm}^{-1}, v_{2}(2)$ at $\sim 548 \mathrm{~cm}^{-1}, v_{2}(3)$ at $\sim 531 \mathrm{~cm}^{-1}$ and $v_{2}(4)$ at $\sim 520 \mathrm{~cm}^{-1}$. The absorption band (figure 2 ) corresponding to the tetrahedral complexes of $\mathrm{Ni}^{2+}\left(v_{2}^{*}\right)$ is: $v_{2}^{*}(1)$ at $\sim 449 \mathrm{~cm}^{-1}, v_{2}^{*}(2)$ at $\sim 436 \mathrm{~cm}^{-1}, v_{2}^{*}(3)$ at $\sim 422 \mathrm{~cm}^{-1}$ and $v_{2}^{*}(4)$ at $\sim 412 \mathrm{~cm}^{-1}$.

FTIR spectrum of the composite with the active carbon also clearly shows three regions with a high intensity transmittance (figure $2 b$ ) greater than that of pure spinel. The peak of the tetrahedral complexes of $\mathrm{Co}^{2+}$ ions at $\sim 660 \mathrm{~cm}^{-1}$ looks the clearest without sub-bands. The octahedral IR absorption band of $\mathrm{Co}^{+2}$ and the tetrahedral complexes of $\mathrm{Ni}^{2+}$ split into sub-bands (figure 2b).
FTIR spectrum of the carbon nanotube composite does not have a clearly defined region corresponding to the tetrahedral and the octahedral complexes; however, among the multiple weak peaks in the $400-700 \mathrm{~cm}^{-1}$ range, sub-bands of $\mathrm{Co}^{+2}$ and $\mathrm{Ni}^{2+}$ can be recognized (figure $2 \mathrm{c}$ ).

Figure 3 shows the SEM images of $\mathrm{NiCo}_{2} \mathrm{O}_{4}$ and its composites and demonstrates the surface morphology of the obtained samples. As shown in figure $3 \mathrm{a}, \mathrm{NiCo}_{2} \mathrm{O}_{4}$ has the surface texture typical for spinels. Figure $3 \mathrm{~b}$ and $\mathrm{c}$ shows a uniform distribution of the precipitated phase over the carrier's surface. Particles of composites with active carbon and MWCNTs are agglomerates with sizes of 10-20 and 7-20 $\mu \mathrm{m}$, respectively.

The determined structural adsorption characteristics of the catalysts: specific surface area $\left(S_{\mathrm{sp}}, \mathrm{m}^{2} \mathrm{~g}^{-1}\right)$, porosity $\left(W_{\Sigma}\right.$, $\left.\mathrm{cm}^{3} \mathrm{~g}^{-1}\right)$, micropore volume $\left(W_{\text {micro }}, \mathrm{cm}^{3} \mathrm{~g}^{-1}\right.$ ) and micropore radius $\left(r_{\text {micro }}, \mathrm{nm}\right)$ are presented in table 3 . As can be seen from table 3, all the synthesized samples have a surface area and porosity that are sufficient for the flow of heterogeneous catalytic processes.

The pure $\mathrm{NiCo}_{2} \mathrm{O}_{4}$ has the lowest structural adsorption characteristics that are typical for the condensed bimetallic 


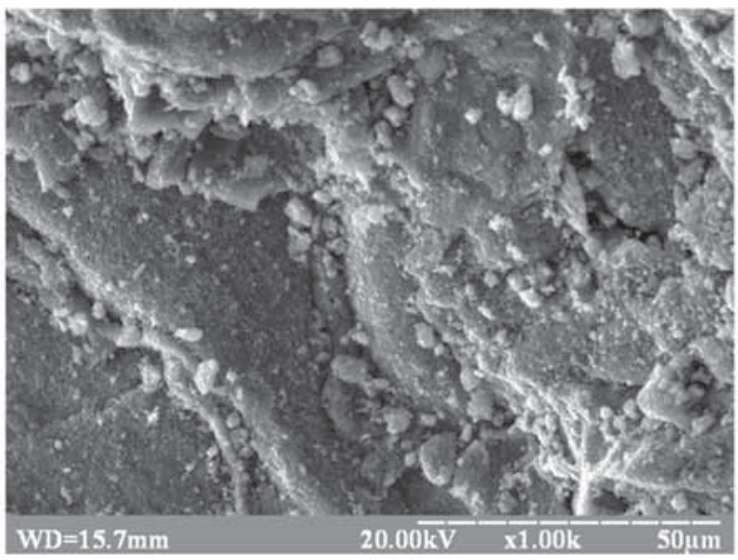

(a)

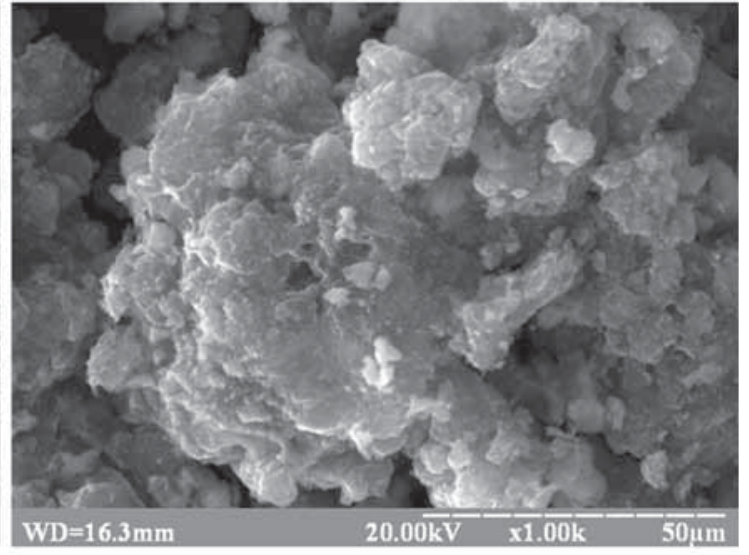

(b)

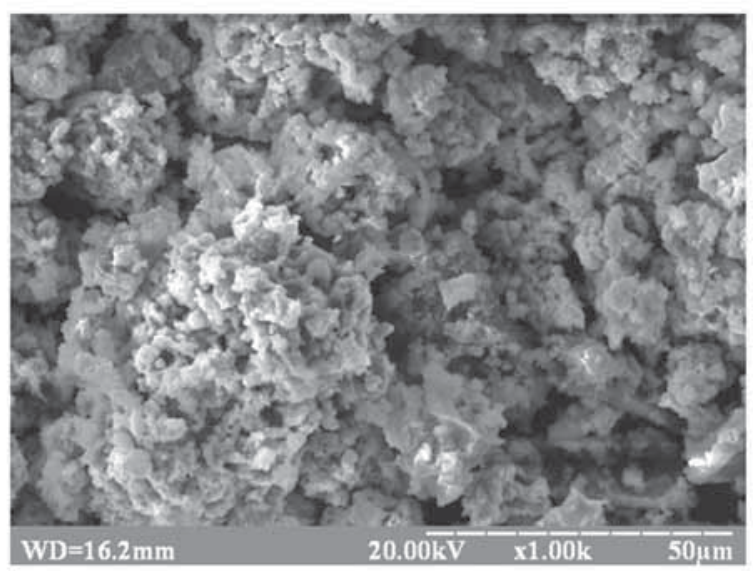

(c)

Figure 3. SEM images of: (a) $\mathrm{NiCo}_{2} \mathrm{O}_{4}$; (b) $\mathrm{AC}-\mathrm{NiCo}_{2} \mathrm{O}_{4}$ and (c) $\mathrm{MWCNT}-\mathrm{NiCo}_{2} \mathrm{O}_{4}$.

Table 3. Structural adsorption characteristics of the obtained catalysts.

\begin{tabular}{lcccc}
\hline Samples & $\begin{array}{c}S_{\mathrm{sp}} \\
\left(\mathrm{m}^{2} \mathrm{~g}^{-1}\right)\end{array}$ & $\begin{array}{c}W_{\Sigma} \\
\left(\mathrm{cm}^{3} \mathrm{~g}^{-1}\right)\end{array}$ & $\begin{array}{c}W_{\text {micro }} \\
\left(\mathrm{cm}^{3} \mathrm{~g}^{-1}\right)\end{array}$ & $\begin{array}{c}r_{\text {micro }} \\
(\mathrm{nm})\end{array}$ \\
\hline $\mathrm{NiCo}_{2} \mathrm{O}_{4}$ & 90 & 0.26 & 0.03 & 0.7 \\
$\mathrm{AC}-$ & 850 & 1.2 & 0.30 & 0.8 \\
$\begin{array}{l}\mathrm{NiCo}_{2} \mathrm{O}_{4} \\
\mathrm{MWCNT}^{-}\end{array}$ & 240 & 2.2 & 0.09 & 1.6 \\
$\mathrm{NiCo}_{2} \mathrm{O}_{4}$ & & & & \\
\hline
\end{tabular}

oxide phase. The composite with active carbon has a very developed surface area, satisfactory porosity and micropores with a diameter of $1.6 \mathrm{~nm}$. The composite on the basis of MWCNTs shows a good surface area and a well-developed porosity. However, the micropore volume of $0.09 \mathrm{~cm}^{3} \mathrm{~g}^{-1}$ is only $4 \%$ of the total porosity for MWCNT- $\mathrm{NiCo}_{2} \mathrm{O}_{4}$, which is completely insignificant, whereas the part of micropores for $\mathrm{AC}-\mathrm{NiCO}_{2} \mathrm{O}_{4}$ is $25 \%$.
Figure 4 shows the results of catalytic experiments, which illustrate the high catalytic activity of all the synthesized samples. The hydrolysis of borohydride takes place less intensively in the presence of a composite, MWCNT- $\mathrm{NiCO}_{2} \mathrm{O}_{4}$. The hydrolysis of borohydride begins rapidly in the presence of pure $\mathrm{NiCo}_{2} \mathrm{O}_{4}$ spinel, but the reaction rate is reduced after $200 \mathrm{~s}$ and the intensity of the process decreases significantly.

The half-transformation time $\left(T_{1 / 2}, \mathrm{~s}\right)$ and reaction rate constants $\left(K, \mathrm{~s}^{-1}\right)$ were calculated for three tested samples to quantify characterization and comparison of their catalytic activities as shown in figures 5 and 6 .

As can be seen from figures 5 and 6 , the shortest halftransformation time and the highest rate constant of the investigated reaction correspond to the composite $\mathrm{AC}-\mathrm{NiCO}_{2} \mathrm{O}_{4}$, i.e., to the catalyst with the largest surface area and microporosity. Pure spinel, despite its weak structural adsorption characteristics, shows a greater catalytic activity compared to a carbon nanotube-based composite.

Thus, the high catalytic activity of nickel-cobalt spinel is proved in the model reaction of hydrolysis of borohydride. In the creation of spinel composites, active carbon shows itself 


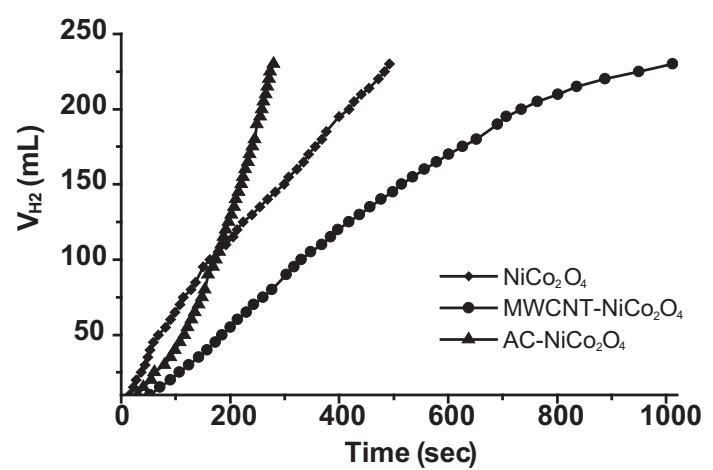

Figure 4. Rate of $\mathrm{NaBH}_{4}$ hydrolysis.

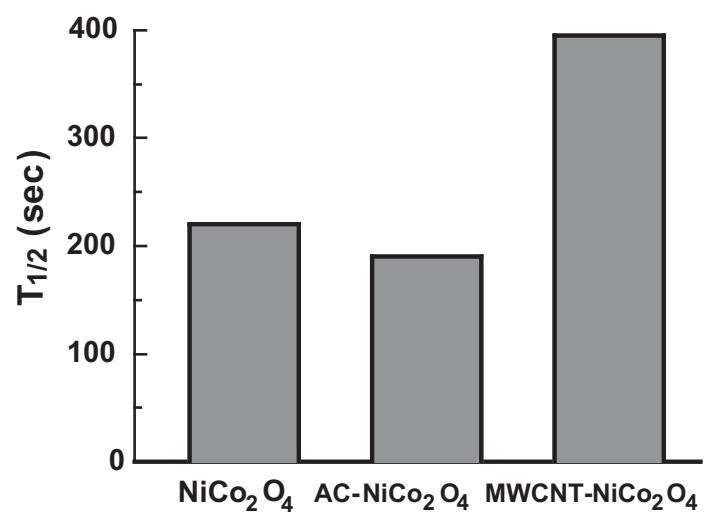

Figure 5. Time of $\mathrm{NaBH}_{4}$ half-transformation.

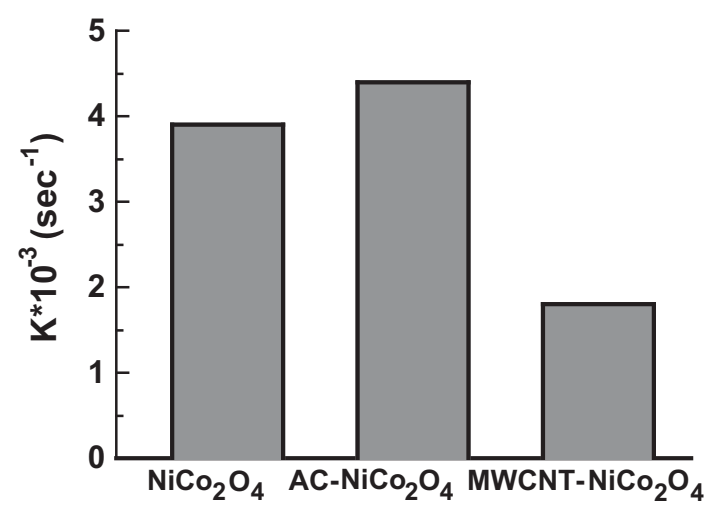

Figure 6. Rate constants of $\mathrm{NaBH}_{4}$ hydrolysis.

to be a more efficient carrier for the catalytically active mass of spinel as compared to MWCNTs.

The obtained data confirm the possibility of using pure $\mathrm{NiCo}_{2} \mathrm{O}_{4}$ and the composites with their participation in electrochemical energy storage/conversion systems due to their high catalytic activity, the simplicity of the synthesis method and economic efficiency in comparison with conventional platinum group metal-based systems.

\section{Conclusion}

The obtained experimental results are consistent with the known data about the effect of the structure adsorption characteristics of materials on their catalytic activity in heterogeneous catalytic processes. The current research demonstrates that nickel-cobalt spinel and its composites with active carbon and MWCNTs are effective catalysts for hydrogen evolution reactions; however, the developed surface area and porosity are necessary, but insufficient for the effective course of this heterogeneous catalytic process. On the basis of active carbon, the composite is more catalytically active as compared to the MWCNTs-based composite, not only due to its higher surface area, but also its developed microporosity.

\section{References}

[1] Acar C and Dincer I 20181.13 Hydrogen energy. in: Comprehensive energy systems I Dincer (ed) (Elsevier Inc.) Vol 1 p 568, https://doi.org/10.1016/b978-0-12-809597-3.00113-9

[2] Dincer I and Acar C 2018 Int. J. Hydrogen Energy 438579

[3] Acar C and Dincer I 20184.24 Hydrogen energy conversion systems. in: Comprehensive energy systems I Dincer (ed) (Elsevier Inc.) Vol 4, p 947, https://doi.org/10.1016/ b978-0-12-809597-3.00441-7

[4] Chandra M and Xu Q 2006 J. Pow. Sou. 156190

[5] Braesch G, Bonnefont A, Martin V, Savinova E R and Chatenet M 2018 Electr. Acta 273483

[6] Lima F H B, Pasqualeti A M, Molina Concha M B, Chatenet M and Ticianelli E A 2012 Electr. Acta 84202

[7] Oliveira V L, Sibert E, Soldo-Olivier Y, Ticianelli E A and Chatenet M 2016 Electr. Acta 209360

[8] Oliveira V L, Sibert E, Soldo-Olivier Y, Ticianelli E A and Chatenet M 2016 Electr. Acta 190790

[9] Jusys Z and Behm R J 2015 Electr. Com. 609

[10] Xu D, Zhang H and Ye W 2007 Catal. Com. 81767

[11] Molina Concha B and Chatenet M 2009 Electr. Acta 54 6119

[12] Xu D, Cui Z, Yang J, Yuan M, Cui X, Zhang X et al 2017 Int. J. Hyd. En. 4227034

[13] Chowdhury A D, Agnihotri N and De A 2015 Chem. Eng. J. 264531

[14] Zhou Y, Li S, Chen Y and Liu Y 2017 J. Pow. Sou. 35179

[15] Oliveira R C P, Milikić J, Daş E, Yurtcan A B, Santos D M F and Šljukić B 2018 Appl. Cat. Env. 238454

[16] Wei L, Dong X, Ma M, Lu Y, Wang D, Zhang S et al 2018 Int. J. Hyd. En. 431529

[17] Chou C C, Hsieh C H and Chen B H 2015 Energy 901973

[18] Şahin Ö, Kılınç D and Saka C 2016 J. En. Inst. 89617

[19] Li Z, Li H, Wang L, Liu T, Zhang T, Wang G et al 2014 Int. J. Hyd. En. 3914935

[20] Cai H, Liu L, Chen Q, Lu P and Dong J 2016 Energy 99129

[21] Zou Y, Yin Y, Gao Y, Xiang C, Chu H, Qiu S et al 2018 Int. J. Hyd. En. 434912

[22] Manna J, Roy B, Vashistha M and Sharma P 2014 Int. J. Hyd. En. 39406

[23] Guo J, Hou Y, Li B and Liu Y 2018 Int. J. Hyd. En. 43 15245 
[24] Kılınç D, Şahin Ö and Saka C 2018 Int. J. Hyd. En. 43251

[25] Loghmani M H, Shojaei A F and Khakzad M 2017 Energy 126 830

[26] Rakap M and Özkar S 2012 Catal. Today 18317

[27] Xu Y, Chen J, Wu C, Chen Y, Li J and Li Z 2016 Int. J. Hyd. En. 4116344

[28] Ma M, Ouyang L, Liu J, Wang H, Shao H and Zhu M 2017 J. Pow. Sou. 359427

[29] Vernekar A A, Bugde S T and Tilve S 2012 Int. J. Hyd. En. 37 327

[30] Li F, Arthur E E, La D, Li Q and Kim H 2014 Energy 7132

[31] Huang M, Ouyang L, Chen Z, Peng C, Zhu X and Zhu M 2017 Int. J. Hyd. En. 4222305

[32] Yang C C, Chen M S and Chen Y W 2011 Int. J. Hyd. En. 36 1418

[33] Özdemir E 2015 Int. J. Hyd. En. 4014045

[34] Tang M, Xia F, Gao C and Qiu H 2016 Int. J. Hyd. En. 4113058

[35] Zhang X, Sun X, Xu D, Tao X, Dai P, Guo Q et al 2019 Ap. Surf. Sci. 469764

[36] Wei Y, Huang X, Wang J, Yu H, Zhao X and Cheng D 2017 Int. J. Hyd. En. 4225860

[37] Ding J, Li Q, Su Y, Yue Q, Gao B and Zhou W 2018 Int. J. Hyd. En. 439978

[38] Wu Y, Wu X, Liu Q, Huang C and Qiu X 2017 Int. J. Hyd. En. 4216003

[39] Yan Y, Liu Y, Ni W, Wu J, Mingkai L and Tianxi L 2016 Chem. Nano Mat. 21077

[40] Darbar D, Anilkumar M R, Rajagopalan V, Bhattacharya I, Elim H I, Ramakrishnappa T et al 2017 Ceram. Int. 44 4630

[41] Shi X, Bernasek S L and Selloni A 2018 Surf. Sci. 677278
[42] Jadhav A R, Bandal H A, Chaugule A A and Kim H 2017 Electr. Acta. 240277

[43] Li J, Xiong S, Liu Y, Zhicheng J and Yitai Q 2013 ACS Ap. Mat. Interf. 5981

[44] Tseng C C, Lee J L, Liu Y M, Ming-Der G and Youn-Yuen S 2013 J. Tai. Inst. Chem. En. 44415

[45] Raut S S and Sankapal B R 2017 J. Col. Int. Sci. 487 201

[46] Lesani P, Babaei A, Ataie A and Mostafavi E 2016 Int. J. Hyd. En. 4120640

[47] Adhikari H, Neupane D, Ranaweera C K, Candler J, Gupta R C, Sapkota S et al 2017 Electr. Acta. 225514

[48] Peres A P S, Lima A C, Barros B S and Melo D M A 2012 Mat. Let. 8936

[49] Xiao X, Li Y, Chen N, Xing X, Deng D and Wang Y 2017 Mat. Let. 195123

[50] Peng S, Hu Y, Li L, Han X, Cheng F, Srinivasan M et al 2015 Nan. En. 13618

[51] Nirmalesh N and Subramanian S 2015 Electr. Acta. 173290

[52] Chen Y, Gan H, Jie-Hao G and Li-Tao C 2018 J. Alloys. Comp. 7606

[53] Su Y Z, Xu Q Z, Chen G F, Cheng H, Nan L and Zhao-Qing L 2015 Electr. Acta. 1741216

[54] Mohamed S G, Attia S Y and Allam N K 2017 Mat. Tod. En. 4 97

[55] Li G, Li L, Shi J, Yuan Y, Li Y, Zhaoa W et al 2014 J. Mol. Cat. 39097

[56] Diao G, Li H, Liang H, Ivanenko I, Dontsova T and Astrelin I 2018 Nan. Br. Rep. Rev. 131850036

[57] Rathod V, Anupama A V, Kumar R V, Jali V M and Sahoo B 2017 Vibr. Sp. 92267 